\title{
6 \\ Between Knowledge and Truth
}

The worldwide economic shift from industry to information has meant that knowledge is increasingly characterized as the primary driver of national development. Countries around the world are reforming their higher education systems to support research and knowledge production, and universities are increasingly pressured to produce high-quality, relevant, and marketable research. Framed within this global race for knowledge, development experts lament the fact that Arab nations lag far behind in scientific research and have few highimpact scholars or publications in Arabic (Zou'bi, Mohamed-Nour, el-Kharraz, \& Hassan, 2015). The technical literature links the region's low levels of scientific research to stagnant economies, arguing that the region needs more scientific, technical, and applied research to support national development.

In the dominant conception, knowledge production is characterized as a largely mechanical affair: time and resources go into the university, and knowledge emerges in the form of publications and patents. Numerous reports highlight the bureaucratic and institutional obstacles to conducting academic research in the region, including a lack of funding and few incentives for professors. They suggest that research productivity can be improved with policies, such as linking faculty members' promotion and pay rises to publications. This focus on productivity has put pressure on Arab academics to publish in internationally indexed journals and often in English (Hanafi, 2011; Hanafi \& Arvanitis, 2014). It also creates perverse incentives that lead to the inflation of numbers through low-quality publications or the recruitment of foreign scholars to publish at an institution, resulting in research that may be irrelevant to local communities.

This chapter argues that the technical literature focuses on individual and institutional practices while ignoring the deeper historical 
and geopolitical factors that shape research production. Drawing on cross-national data, I argue that disparities in research productivity map onto linguistic, economic, and geopolitical power. While state support, institutional resources, and faculty incentives can and do matter, they do not erase the fundamental structural realities that shape the global academic system. Research and patent production are highly concentrated in North America and Europe, supported by the hegemonic status of English (Hanafi \& Arvanitis, 2014). Middle-income countries in the Arab world actually have scholarly productivity in line with or above similar nations globally and also have impressively high rates of international co-authorship.

Fundamentally, the focus on productivity ignores the fact that knowledge creation is a creative and social process. It entails collaboration among scholars (Bamyeh, 2015), as well as autonomy, motivation, stability, and a social mandate. Intellectual freedom allows scholars to examine, debate, and critique ideas. In the contemporary Arab world the free pursuit of truth is, more often than not, perceived as a threat to ruling regimes (Waterbury, 2020). Arab states are often unwilling to give researchers the freedom they need, or are unable to give them the stability and the social mandate they need, to be productive (Almansour \& Kempner, 2017; George, 2003; Waterbury, 2020).

Recognizing these realities does not discount the need for research on the pressing issues in the Arab world. In fact, it makes it even more important to protect the autonomy, stability, and support for the research that is being done within the region. Supporting research is a long-term process of institution building. More pointedly, supporting research also means supporting faculty members, who are often at the front lines of university-reform initiatives. This chapter concludes with a call for an expansive view of the role of research in development; to view the university's research mission in primarily utilitarian and economic terms is narrow minded. Some of the most pressing questions that the region faces involve the messy social sciences and the so-called fluffy humanities: questions of identity, cultural difference, morality, civic engagement, and subjective well-being.

\section{The University and the Knowledge Society}

One of the university's core purposes has always been to preserve, create, and disseminate knowledge. Increasingly, the emphasis on knowledge production is closely tied to discourses about the changing economy, where knowledge is viewed as the driver of innovation, economic growth, and development (Frank \& Meyer, 2007). Sociologist 
Gili Drori has examined the reasons that the discourse of science is so powerful in the contemporary imagination. She argues that dominant discursive constructions in the field of international development create clear links between science, technology, and development. In this model, investments in basic science lead to technological innovation, which then drives advances in economic development. In her research Drori (1993) finds that the links between science and economic development are not straightforward at all; in fact, she finds that in the least developed countries there is no statistical relationship between investments in science and subsequent technological innovation or economic development. Yet, in global development, scientific research is overwhelmingly viewed as a primary means to progress and development.

Accordingly, investment in research and development has increased steadily over the past few decades. Data shows that in 1996 roughly 1.39 per cent of the world's GDP per capita was devoted to research and development (R\&D), which increased to 1.54 per cent in 2006 and 1.73 per cent in 2018 (UIS, 2019). This represents an almost 25 per cent increase in global investment in R\&D over the past twenty years. In 2015, as part of the SDGs, the United Nation's global agenda for development, countries committed to supporting scientific research and innovation. SDG 9 states that all countries will "build resilient infrastructure, promote inclusive and sustainable industrialization and foster innovation." This commitment includes a specific target for R\&D and calls on countries to increase expenditure in R\&D as a proportion of overall GDP. This call has been heeded in the Arab world as well, where numerous Arab governments and regional initiatives have committed to increasing locally relevant research production (Badran, 2018).

The emphasis on science and innovation has had important implications for higher education. Universities produce the majority of new research and development worldwide (Badran, 2018), and in the global era, universities are increasingly orienting themselves towards research excellence (Ramirez, 2010; Ramirez \& Tiplic, 2014). At the same time, neoliberal policies have affected public support for research, and discourses of efficiency have focused attention on research outputs. In the post-Second World War era, countries devoted public funding to research and science in the name of national development. In the contemporary neoliberal era, the focus on outcomes and efficiency has contributed to a "contractual" vision of research, where benefits of research are articulated primarily in terms of anticipated benefits to the economy. Geuna (2001) describes "the quest for nationally relevant university research" as resulting from neoliberal policies that seek "accountability and cost reduction" (p. 609). The changes have led to 
more industry funding and more applied research. Neoliberal practices have also raised concerns over a "research productivity gap" where research production is concentrated increasingly in elite and wellfunded institutions and conducted by declining numbers of full-time professors. These discourses have had great currency in the Arab world (Mazawi, 2007), where the region has largely been considered to be failing in knowledge production, and where knowledge economy discourses have been associated with reforming universities and science and innovation systems.

\section{"Far from Innovative"}

For at least two decades development publications have argued that the research production of Arab universities is low and lacks innovation. In the early 2000s the United Nations Development Programme published a series of reports on the state of human development in the Arab world, known as the Arab Human Development Report (AHDR). The first, published in 2002, argued that Arabic scholarship had little impact in international academic circles, with few publications from the Arab world being widely cited (Sakr, 2004). The first AHDR found that in 1987 only one paper from each of Egypt, Saudi Arabia, Kuwait, and Algeria was cited more than forty times, while in the United States 10,481 papers were quoted more than forty times, and in Switzerland 523 papers (UNDP, 2002, p. 67). Similarly, the 2003 version, Building a Knowledge Economy, focused on knowledge production and dissemination. Over forty scholars, including many Arab scholars based in the region, wrote background papers in English and Arabic for the report (UNDP, 2003). The report was critical of the scholarship in the region: "Despite the increase in the number of published Arabic research papers in specialized global periodicals, Arabic research activity continues to be far from innovative" (p. 70). This discourse, which characterizes the Arab world as having a "knowledge deficit," has been critiqued for placing the blame for low publication rates on Arab scholars and universities, rather than recognizing the myriad factors that affect publication and citation rates (Mazawi, 2007; Sakr, 2004).

Yet, nearly two decades later, discussions of knowledge production in the Arab world continue to frame the region as failing. A 2013 WB publication on higher education governance in the Arab world, Benchmarking Governance as a Tool for Promoting Change, states that, lacking a better indicator of student learning, "the number of scientific citations per 100,000 inhabitants is used as a proxy for intellectual contribution to the world body of knowledge" and that, "in this regard, 
the contribution of MENA countries, as in other developing countries like Malaysia, Chile, and Colombia, is very limited compared to OECD countries (Jaramillo, 2013, p. 12). Statements like this are overly simplistic and overtly biased. The link between academic publications and what the WB has called a country's "intellectual contribution to the world body of knowledge" is anything but straightforward. By simplifying the link between publications and intellectual contribution, publications such as these ignore the variation in structural conditions across world regions.

In the development literature the region's lack of scientific innovation is framed as an impediment to the creation of vibrant knowledge economies. One critique is that, in the Arab world, governments provide most of the funding for research, and there is still little privatesector investment in research and development, which can undermine the economic impact of science and innovation (Badran, 2018). The 2003 AHDR notes that the Arab university's low quality "limits the ability of research centers ... to achieve advanced levels of scientific and technological performance" (UNDP, 2003, p. 71). Similarly, a UNESCO report on the state of science in the region states that science and technology policies in the Arab world "have failed to catalyse knowledge production effectively or add value to products and services" and suggests that this is because the incentives and interests of academic researchers are far removed from the needs and priorities of the business community (Zou'bi et al., 2015, p. 435).

The blame for low research production is often placed on higher education, with critiques being made of rote memorization, heavy teaching loads, and a lack of facilities (Dohjoka, Campbell, \& Hill, 2017). Development actors also tend to place the burden of research largely on individual faculty members and suggest that research productivity can be improved with better resources and better incentives. This type of discussion implicitly frames knowledge production as a mechanical affair: faculty members' time and resources go into the university, and knowledge emerges in the form of publications and patents. In fact, the professional lives of Arab academics are much more complicated.

\section{Academic Researchers as Knowledge Producers}

Academics in the Arab region vary significantly in terms of their academic training, professional goals, and institutional contexts. A study on research productivity commissioned by the International Institute of Education found that only a small percentage of Arab faculty members would be considered "research active," compared to two-thirds of the 
professors at top universities worldwide (Bhandari \& Amine, 2012). This finding is not an anomaly; numerous studies have found that research is a low priority for many academics in the region (Almansour \& Kempner, 2017; Amer, 2019; Austin, Chapman, Farah, Wilson, \& Ridge, 2014). In addition, Arab academics face several institutional and structural barriers when conducting research, including high teaching loads, weak institutional support for research, a lack of or poorly equipped facilities, limited access to academic journals, and little emphasis on research in promotion decisions (Amer, 2019; Herrera, 2006).

A lack of funding for research is recognized as a major impediment. The 2003 AHDR focused on the problems posed by low resources: "The under-funding of higher education impacts negatively on science and technology in particular, because these fields require the provision and renovation of costly special facilities, equipment and materials" (UNDP, 2003, p. 72). A lack of financial support means that the research that is done is on a relatively small scale. Dr. Karim Nasr, Dean of Business Administration at the University of Balamand in Lebanon, explained: "We do some good research, highly relevant and useful, but on an international scale it is minimal. And the reason for this is, we are doing it from a very humble set of resources on a local level. Budgetary allocations to research - if the university does not have a budget for research, it does not happen. There is no other source ... from the government or abroad, it doesn't exist ... not in the sense of a sizable amount that would drive research and make it comparable in terms of the West."

Throughout the low- and middle-income nations in the region, professors' salaries are generally low (Waterbury, 2020). Waterbury (2020) draws on data from Al-Fanar that shows that Arab professors are largely missing from the middle class, meaning that in general, outside the Arab Gulf region and possibly Lebanon, "a professor's salary does not provide a comfortable middle-class standard of living" (p. 274). One Egyptian professor writes in a public post titled "Yes, I Am a University Professor" that he only makes EGP 6,000 a month (USD 375). He asks, "How can this be enough for providing the basic needs for our home, wife, children, transportation, clothing, research studies, scientific conferences? ... There's no status for someone, however successful they are in their scientific field, if they're unable to buy clothes for themselves or reach their university in a dignified way" (Badawi, 2019). L. Anderson (2012) similarly laments that the base salary of custodians at the American University in Cairo is higher than the base pay of public university faculty members.

Other studies have found that, given their low salaries, many Arab professors moonlight to make additional money (Almansour \& 
Kempner, 2017). Waterbury (2020) argues that one of the most pervasive myths of higher education in the Arab world is that of the "full-time professor," when in fact most professors in the region have secondary employment, often due to low salaries. He cites studies that find that anywhere from 20 to 45 per cent of university instructors work outside their home institutions in Morocco (Bourqia, 2011; Cherkaoui, 2011). This often takes the form of teaching on contract at private universities. Regardless, Almansour and Kempner (2017) point out that the choice to take on additional work further reduces their time to conduct research.

A lack of funding for research, combined with low salaries, means that many academics must fund their own research. Unsurprisingly, in a region-wide survey of over 650 researchers across the region conducted by Al-Fanar, 84 per cent reported using their own money to conduct research, and 49 per cent of researchers in the lower-middleincome countries of the region stated they would move abroad for improved salaries (Amer, 2019).

Additionally, many academics lack access to the journals or online databases they need to conduct their research. In its survey of researchers Al-Fanar found that roughly 50 per cent of all those surveyed did not have reliable access to the internet at their institutions, and 52 per cent did not have free access to academic journals (Amer, 2019). Other surveys with Arab academics have found similar concerns. In a survey with Arab social scientists a large proportion reported that they did not have access to needed sources from their libraries, and many stated that they could not get sources in Arabic from online databases (Hanafi \& Arvanitis, 2014). Similarly, after interviewing over seventy faculty members from fourteen countries throughout the region about their views on research, Almansour and Kempner (2017) quote one Tunisian academic who quipped, "Technology did not reach us yet" (p. 228).

In my own research in the region I often spoke to academics who were frustrated by this lack of support and had to be creative in the face of challenges. One professor at Mohammed V University in Morocco told me that although he did have access to well-known databases of academic journal articles, this access was only available on campus, and it was hard for him to find access to up-to-date research. He often asked colleagues at universities in Europe or the United States for access to certain journals, essentially relying on informal networks to obtain knowledge. In the natural and medical sciences other barriers include delays in acquiring supplies, which may be held up in transit or customs; excessive fees on importing necessary equipment; security clearances for recruiting researchers; and a lack of experimental trials in the medical sciences (Amer, 2019). 
The lack of resources is only one of the issues that Arab academics face. Professors throughout the region perceive a lack of institutional support for research and the general absence of a research culture, despite being expected to produce research in the name of the knowledge economy. Studies of the working conditions of faculty members in the region have found that high teaching loads and a general prioritization of teaching in promotion decisions disincentivize research (Almansour \& Kempner, 2017; Austin et al., 2014). Similarly, Waterbury (2020) cites a survey of Egyptian faculty members in which 86 per cent believed that the legislative and institutional atmosphere was not conducive to research (p. 281). Along these lines, Almansour and Kempner (2017) report that "research is not woven into the fabric of the universities" (p. 228). Specific obstacles include a lack of incentives to conduct research, little administrative support, and the need to navigate excessive bureaucracy when conducting research. An Egyptian professor whom they interviewed stated, "Research is not taken seriously, it's perceived by faculty as a means for promotion, it has no value" (p. 229). The result is a lack of motivation for research. One of their key findings was that "the lack of motivation to conduct research is a serious challenge" for many (p. 224). The result of these obstacles is that most academics in the region portray conducting research as what they call a "self-effort" rather than part of a professional obligation (p. 228). Various studies of the professoriate in the region support the idea that promotion is based primarily on tenure, rather than on research productivity. Boughazala, Ghazouani, and Ben Hafaiedh (2016) write, in the case of Tunisia, notably one of the most research-productive countries in the region, that "faculty members' remuneration is almost totally independent of their effort and their performance" (p. 8). Similarly, Waterbury (2020) quotes a professor from Morocco who states that "two articles in even mediocre journals" will be enough for promotion (p. 279).

A cross-national study of social scientists in the Arab world, conducted by the Arab Council for Social Sciences in 2015, found that universitybased research centres were rare in the region. The majority of the 436 social science research centres were based outside of universities. Moreover, those based within universities were concentrated in a few countries, with over half located in only two countries: Algeria and Egypt (57 per cent). Meanwhile, many countries in the region had either zero or one university-based social science research centre (Bamyeh, 2015, p. 19), including Oman (one), Kuwait (one), Syria (one), UAE (two), Qatar (two), Tunisia (none). The council argues that university-based research centres not only offer institutional infrastructure to scholars but also can strengthen the links between teaching and research. 
Unsurprisingly, many academics in the Arab world seek to emigrate in search of professional opportunities, and the lack of stability after the Arab Spring has only increased the academic brain drain (Plackett, 2016c). In a region-wide survey of 650 researchers conducted by $\mathrm{Al}$ Fanar in 2019, 91 per cent stated that they would like to work elsewhere, and this high proportion cut across age, country, and discipline (Amer, 2019). The highest proportions who wanted to leave were researchers in countries affected by conflict, namely Syria, Yemen, and Libya, where an average of 95 per cent reported wanting to leave. Meanwhile, the survey found that in the Arab Gulf states, despite having better salaries on average, 81 per cent of researchers wanted to emigrate and pointed to a lack of freedom as a primary rationale. Interestingly, although the most sought-after destinations were Europe (68 per cent) and North America (55 per cent), many researchers in the region were also open to emigrating to Arab Gulf states (34 per cent) or other nonGulf Arab nations (27 per cent). Broadly speaking, the high proportions of researchers who were interested in emigrating points to a high degree of dissatisfaction.

A lack of security and academic freedom affects faculty members' ability to conduct research. In the Gulf states the nature of academic work compounds with an unstable geopolitical environment to undermine a sense of stability. In most GCC nations higher education institutions rely on significant proportions of expatriate faculty members, who, like all workers, are on temporary contracts and can be fired at will. In the UAE they cannot gain tenure and are hired primarily on a contract basis, in contrast to Emirati faculty members who are able to gain a significant degree of job security (Austin et al., 2014, p. 544). In their study Austin et al. (2014) interviewed twenty-nine expatriates working in UAE public universities and found that they viewed their status as essentially temporary workers and expressed the idea that they felt "expendable," which undermined their sense of belonging and commitment to their institutions. There was a pervasive sense of insecurity. One professor explained: "We cannot do anything because somebody may say 'you go,' and then you have to go ... If you [raised a concern] ... you'd get fired. Your contract - no more. After 3 months, you will have to leave" (p. 549). In short, the nature of labour in the Gulf states undermines the creation of a research community because academics' contracts are "temporary, completely dependent on administrative decisions, and susceptible to termination at any time" (p. 550). This lack of job security is closely related to concerns over restricted academic freedom. Al-Fanar finds that unlike in the lower- and middle-income countries in the region where salaries are a major concern, 
one of the primary reasons that faculty members in the GCC want to emigrate is a lack of academic freedom and job security. According to their survey, 62 per cent of researchers in the Gulf would move abroad for more academic freedom, compared to only 26 per cent who sought higher salaries (Amer, 2019).

\section{Ignoring the Structural Realities}

One of the most problematic assumptions of development discourses on research is that scholarly outputs are primarily a result of internal investments in productivity rather than a result of structural conditions. In contrast to the development literature, scholars based within the region point to a broader range of issues facing knowledge production, including the fragmentation of academic communities across generations (Bamyeh, 2015). Fundamentally, the global academic system is deeply unequal: high-impact journals are overwhelmingly based in North America and Europe; they primarily publish in English; and they cater to topics that those regions find interesting, ignoring histories of colonization and economic oppression that discount non-Western knowledges (Hanafi \& Arvanitis, 2014; Keim, 2008).

Sari Hanafi and Rigas Arvanitis, two of the leading scholars of knowledge production in the Arab world, argue that the "publication system in the social sciences, as in all sciences, is thus a global power structure" (2014, p. 724). Informed by their argument that many factors, including "the political economy of publication," has affected scientific publication in the Arab world, in this section I analyse the structural conditions that shape productivity in the Arab world. Specifically, drawing on data from the WB's World Development Indicators, I analyse data on the number of scholarly publications per 100,000 residents. This indicator is an imperfect measure of actual output - it likely captures publications in the natural sciences better than those in the social sciences and does not take into account applied or policy publications. It also likely better captures scholarship published in English than in Arabic because, according to Waast, Arvanitis, Richard-Waast, and Rossi (2010), "journals that are present in the large bibliographical databases have strong biases against non-English languages and particularly Arabic" (p. 176). Nonetheless, they serve as a one indicator of publications, and governments may be particularly sensitive to these numbers because they are used to measure progress to the SDGs.

Table 6.1 shows the average number of articles published in scientific and technical journals per 100,000 residents between 2004 and 2016 in different world regions. It is clear that there is substantial variation across 
world regions. The table also shows that scientific publications have increased over the past decade around the world, including in the Middle East and North Africa. Scientific publications increased in the Middle East and North Africa from eight per 100,000 people in 2004 to twenty-three in 2016. This is one of the largest growth rates in the world after South Asia and is nearly identical to the growth rate in middle-income countries worldwide. The finding is in line with prior work that has revealed significant increases in research production in the Arab world over the past thirty years, which suggest that the expansion of higher education and the intensification of knowledge production (enhanced by technology and the internet), as well as the institutionalization of research cultures in the region, may all be factors leading to growth (Siddiqi, Stoppani, Anadon, \& Narayanamurti, 2016). In an analysis of publications from North Africa, Waast et al. (2010) found "a rapid increase" in publications by North Africans "from 2,000 in 1985 to over 6,000 new documents per year in 2005" (p. 177). Similarly, Waast and Rossi (2010) found what they call "noteworthy" increases in productivity, particularly in North Africa, stating that "scientific activity gained tremendous momentum during the last twenty years, especially in Maghreb" (p. 343).

That said, despite increases in the Middle East and North Africa region, research production is highly concentrated in two world regions: North America (136 publications per 100,000 in 2016) and Europe and Central Asia (86 publications per 100,000 in 2016). These figures are three to four times larger than the next world region, East Asia, and thirty to fifty times larger than rates in sub-Saharan Africa. Such large disparities in publication rates are not simply a reflection of different levels of funding or any specific public policy concerning research. They reflect long-standing historical trajectories and ongoing dominance of Western and northern academia in the global economic and academic system. The historical dominance of northern universities means that they can continue to recruit the best scholars from around the world, and the dominance of English in the global academic system means that their publications are the most widely published and disseminated worldwide.

Arguably the single largest predictor of scientific publication rates is a country's GDP per capita. Figure 6.1 illustrates the bivariate relationship between GDP per capita and a nation's publications per 100,000 residents in 2018 for countries with a GDP per capita under USD 80,000. The grey line on the graph plots the linear relationship among all countries worldwide, excluding those in the Arab Middle East and North Africa, and points to a clear, positive relationship. A simple regression analysis shows that a country's GDP per capita explains 74 per cent of the variation in publication rates cross-nationally. The large and clear 
Table 6.1. Scientific and Technical Journal Articles, per 100,000 People

\begin{tabular}{lrrrrr}
\hline & 2004 & 2008 & 2012 & 2016 & $\begin{array}{l}\text { Growth rate } \\
(2004-16)\end{array}$ \\
\hline East Asia and Pacific & 15 & 23 & 28 & 33 & $118 \%$ \\
Europe and Central Asia & 58 & 71 & 81 & 86 & $50 \%$ \\
Latin America and Caribbean $^{1}$ & 7 & 11 & 14 & 16 & $124 \%$ \\
Middle East and North Africa $^{1}$ & 8 & 13 & 19 & 23 & $188 \%$ \\
All Middle income & 6 & 10 & 13 & 16 & $185 \%$ \\
North America & 122 & 133 & 140 & 136 & $11 \%$ \\
South Asia & 2 & 3 & 5 & 7 & $232 \%$ \\
Sub-Saharan Africa & 1 & 2 & 2 & 2 & $94 \%$ \\
\hline
\end{tabular}

Source: Data accessed through the WB Open Data module for Stata. Indicators IP.JRN. ARTC.SC (Publications) and SP.POP.TOTL (Population) (Azevedo, 2011) 1. The following four countries are included in WB's Middle East and North Africa region but not the book's focus on the Arab Middle East and North Africa: Iran, Israel, Malta, and Djibouti. Using the WB's regional classification of Arab states yields a similarly large growth rate of 1.90 per cent between 2004 and 2016 but a lower overall total (11 per cent in 2016).

association between the wealth of a country and its research productivity suggests clear structural factors at work, factors that are too often ignored in discussions of specific policies and practices that inhibit or incentivize research. Moreover, while it is likely that knowledge production supports innovation and economic development, it is just as likely that national wealth supports the investments necessary for robust higher education, scientific research, and innovation systems.

The figure also shows that the relationship between GDP per capita and publication rates in the Arab Middle East and North Africa states is very different from the global average. The black dots and black line in figure 6.1 show the same relationship for Arab nations in the region. The Pearson's correlation coefficient is only 0.60 , and a simple regression analysis shows that GDP per capita only explains 43 per cent of variation in publication rates. It appears that the Arab Middle East is an exception to the global pattern - national wealth is not as strong a factor in determining scientific publications in the region. Many use this fact to critique science, technology, and innovation policies in the region. The weak relationship documented in figure 6.1, however, is largely determined by six resource-wealthy Arab Gulf states and the countries in conflict in the region. When the six GCC nations are excluded from the analysis, publication patterns in the lower- and middle-income countries in the Arab world reflect global trends.

Figure 6.2 shows the relationship between national GDP per capita and publication rates per 100,000 residents for countries with GDP per capita 
Figure 6.1. Relationship between GDP per Capita and Scientific Publication Rates (2018)

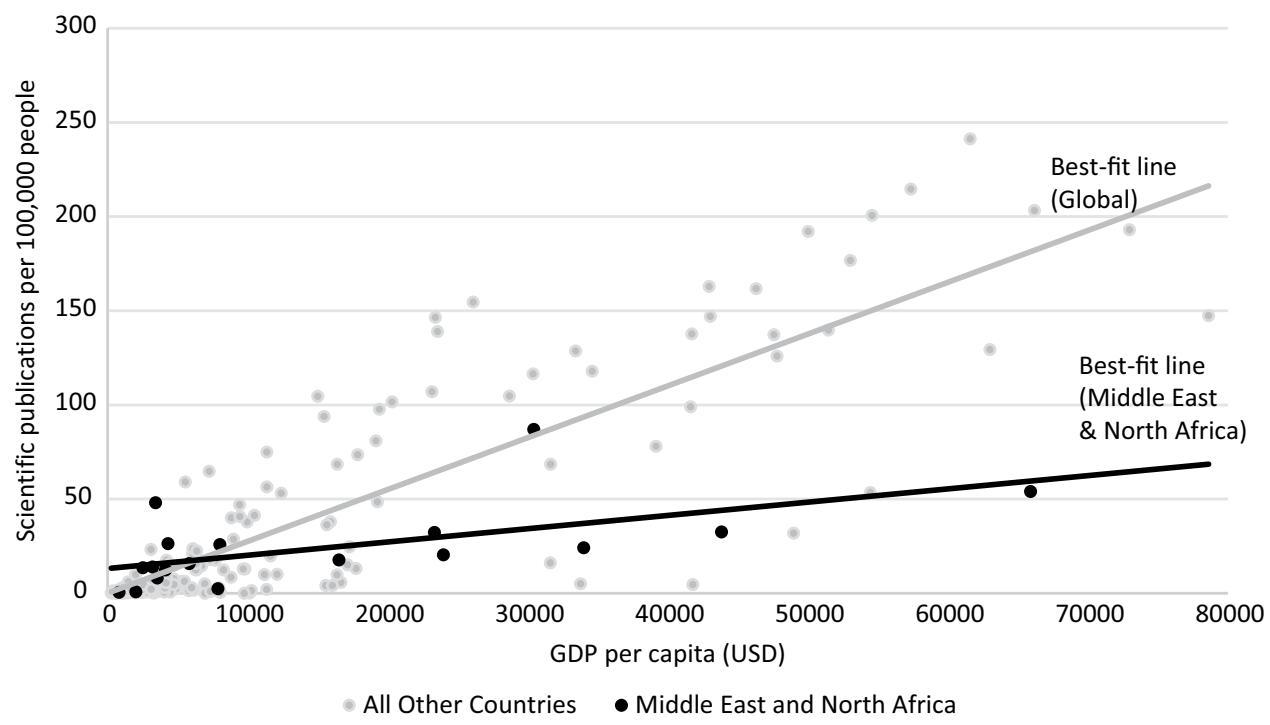

Source: Data accessed through the WB Open Data module for Stata. Indicator IP.JRN. ARTC.SC (Publications); SP.POP.TOTL (Population), and NY.GDP.PCAP.CD (USD GDP per capita) (Azevedo, 2011).

Note: I classify the countries Iran, Israel, Malta, and Djibouti as outside the Arab Middle East and North Africa, although they are included in the WB's Middle East and North Africa region.

of less than USD 10,000. The black line represents the global average for all countries with a GDP of less than USD 10,000, while the dots represent Arab nations' research productivity in 2018, or the most recent year of data available. The figure shows that research productivity in the region is heterogeneous, yet in general, the middle-income countries of the Arab world appear to be doing well in comparison to peer nations. Some nations, such as Tunisia, have publication rates that are significantly higher than the global trend. Jordan and Lebanon also have above-average productivity levels. Other countries, including Morocco, Egypt, and Algeria have publication rates that are similar or slightly higher than expected for their GDP per capita. In contrast, Yemen, Syria, and Libya are well below the global average for their GDP per capita. It is worth noting that these countries have historically benefited economically from natural resource extraction or have recent histories of conflict, which have likely had a negative impact on their research productivity. 
Figure 6.2. Relationship between GDP per Capita and Scientific Publication Rates for Countries with GDP per Capita less than USD 10,000 (2018)

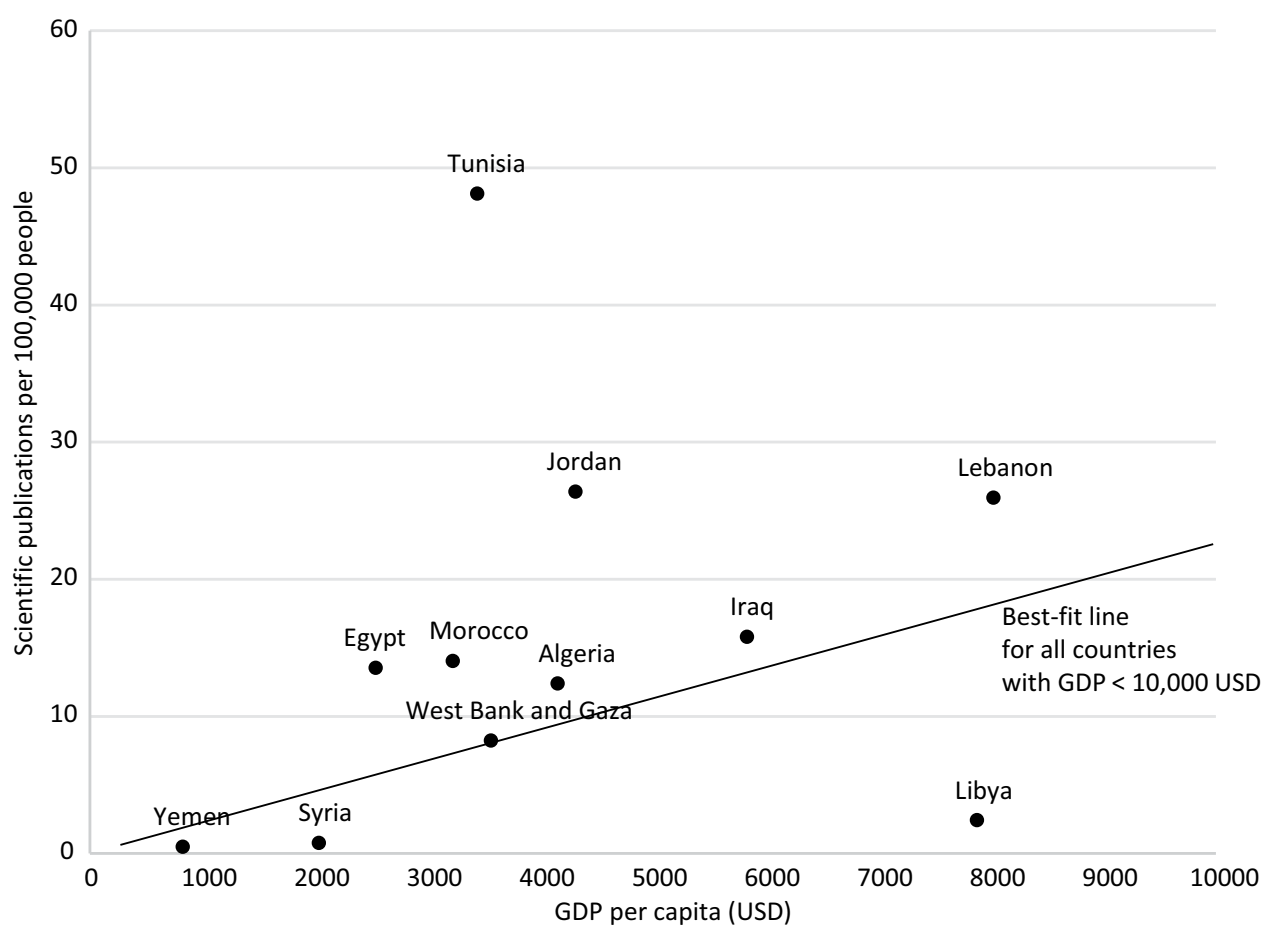

Source: Data accessed through the WB Open Data module for Stata. Indicators IP.JRN. ARTC.SC (Publications); SP.POP.TOTL (Population), and NY.GDP.PCAP.CD (USD GDP per capita) (Azevedo, 2011).

Combined, these figures suggest a broad categorization of countries in the region: first, there are a number of countries with scholarly productivity lower than the global average, including Libya and Yemen, and the countries in the Arabian Gulf. All of these nations rely on resource extraction, and many are experiencing conflict, suggesting that political stability is critical (Almansour, 2016). Second, there are the middle-income countries, which have scholarly productivity rates in line with or above the global averages for countries with similar levels of economic development. Third, there is Tunisia, which stands out in the region and the world, with a productivity rate that is significantly above the global average for middle-income countries. One important takeaway from these findings is that knowledge production in 
the Arab world is not as dire as it might seem. Rather, it is embedded within a broader geopolitical and economic context where global knowedge production is dominated by countries in North America and Europe.

\section{Investing in Science and Research Production}

Noting structural realities is not to say that national policies do not matter. In fact, partially in response to global pressures, Arab governments have committed to making research a national priority. Since 2000 the Council of Ministers of Higher Education and Scientific Research in the Arab World has met regularly to discuss science and technology in the Arab world (Zou'bi et al., 2015). In 2011, UNESCO's Cairo office founded a network of organizations to support emergent technologies in the region, including biotechnology, nanotechnology, and information communications technology. Known as the Network for the Expansion of Convergent Technologies, it connects academia and industry to produce research to support the region's knowledge-based sectors. In 2014, the network organized a regional forum around the theme of galvanizing science education and higher education towards a knowledge-based economy.

Similarly, in 2014, governments of the region endorsed the Arab Strategy for Science, Technology and Innovation in Riyadh, Saudi Arabia. The strategy has three pillars: academic training in science and engineering; supporting scientific research; and promoting regional and international scientific co-operation. It laid out an ambitious set of policies to improve intra-regional co-operation and mobility, including a network of science centres, regional centres of excellence, intra-regional mobility, and partnerships with Arab academics abroad. It also suggests increasing funding for research from the 2014 average of 0.3 per cent of GDP to 3.0 per cent, with $30-40$ per cent coming from the private sector. The strategy identifies fourteen priority areas for research: biotechnology, nanotechnology, information technology, water, food, agriculture and fishing, space, energy, desert sciences, the environment, renewable energy, poverty, and disease (Zou'bi et al., 2015). It is notable that this strategy adopts all of the best practices advocated in the literature, including working closely with the private sector, supporting interdisciplinary research, and focusing on the economic value of research. However, the absence of social sciences and humanities in discussions of research in the region is also striking.

Additionally, many Arab governments have devoted significant funding to supporting research, typically justifying this shift in the 
Table 6.2. Research and Development Expenditure (\% of GDP)

\begin{tabular}{lll}
\hline & $2000-9$ & $2010-16$ \\
\hline Egypt & 0.27 & 0.60 \\
Jordan & 0.39 & 0.72 \\
Morocco & 0.59 & 0.71 \\
Qatar & - & 0.49 \\
Tunisia & 0.67 & 0.66 \\
United Arab Emirates & - & 0.76 \\
\hline
\end{tabular}

Source: Data accessed through the WB Open Data module for Stata. Indicator GB.XPD. RSDV.GD.ZS (Azevedo, 2011).

name of the knowledge economy. Table 6.2 shows gross domestic spending on research and development for six Arab nations for which there is data. The average spending on $R \& D$ increased substantially in Egypt, Jordan, and Morocco after 2010, while percentages in Tunisia remained steady. Before 2000 the percentage in Egypt was roughly 0.20, which increased to 0.27 in the 2000s and has increased to an average of 0.60 since 2010. Since 2010, Jordan, Morocco, and the UAE, have all spent more than 0.70 per cent of their GDP on R\&D. These percentages are less than those of upper-middle-income countries globally, which spend an average of 1.57 per cent, but nonetheless speak to significant increases in the last decade.

Many countries in the region have also developed robust scientific communities inside and outside of academia over the past few decades. According to WDI data, in 2016 Morocco had 1,073 full-time researchers per one million residents, and Tunisia has 1,982 - both of which are comparable to or higher than countries recognized for their strong histories of research such as Chile (493 per million) and Argentina (1,259 per million), as well as emerging research giants such as China (1,196 per million) and Thailand (1,208 per million). This is despite the fact that GDP per capita in these countries is two to three times higher than that in Morocco and Tunisia. In fact, with a 2018 GDP per capita of USD 3,439, Tunisia has more fulltime researchers per million residents than do some European countries, such as Latvia (1,596 per million), whose 2018 GDP per capita was USD 17,858, and Romania (912 per million), whose GDP per capita was USD 12,400 (WDI, 2021). In short, in line with development models and global commitments, Arab nations have increased investments in scientific research and production, a point that development discourses rarely recognize. 


\section{National Science Policy Regimes}

Within the Arab region some countries stand out as outliers. Tunisia has a long history of high research productivity that has been recognized inside and outside the region, and Qatar, despite being well below the global average for its per capita wealth, has witnessed a remarkable increase in scientific activity and academic publications over the past decade. Figure 6.3 shows productivity trends in four countries: Qatar and the UAE, both wealthy GCC countries that have below-average research productivity for their GDP per capita, and Jordan and Tunisia, two middle-income countries that have higher-than-average rates of research productivity.

Although all four countries had similar rates at around fifteen scientific publications per 100,000 people in 2004, publication rates in both Tunisia and Qatar had increased to around fifty publications per 100,000 people by 2016. In contrast, in the UAE and Jordan publication rates have stayed stable at around twenty publications per 100,000 residents. These percentages are calculated as a per capita rate and are therefore sensitive to changes in population. Qatar and Tunisia are much smaller than the UAE, and the UAE's population has been growing rapidly. Nonetheless, they point to impressive gains in Qatar and Tunisia, which other scholars have found as well (Siddiqi et al., 2016).

Scholars of the region have observed that Tunisia has been the leader of scholarly publications in North Africa for at least two decades, due in part to the country's long history of prioritizing scientific research. Prior research has also found that Tunisian academics publish significantly more studies and are cited more often than scholars in Morocco and Algeria (Hammouti, 2010). Tunisia has a long history of supporting cross-national research collaborations particularly with francophone Europe. In 2005 the Ben Ali regime launched an initiative to support research collaborations between Tunisia and international institutions (Fryer \& Jules, 2013), and over the past two decades Tunisia has been one of the largest recipients of funding by the European Union for collaborative research. In addition, Tunisia had institutionalized a culture of research, with established laboratories and years of public support for research, before the 2011 revolution (Waast \& Rossi, 2010). Even after the revolution, it remains among the top funders of scientific research in the Arab world. Tunisia also benefits from institutionalized educational trajectories: it has been one of the best educated countries in the region for some time, with a small and well-educated population and a long tradition of public research universities, ministry support for research, and tight linkages to French academia. 
Figure 6.3. Scientific Publication Rates per 100,000 People, 2004-16 (Select Countries)

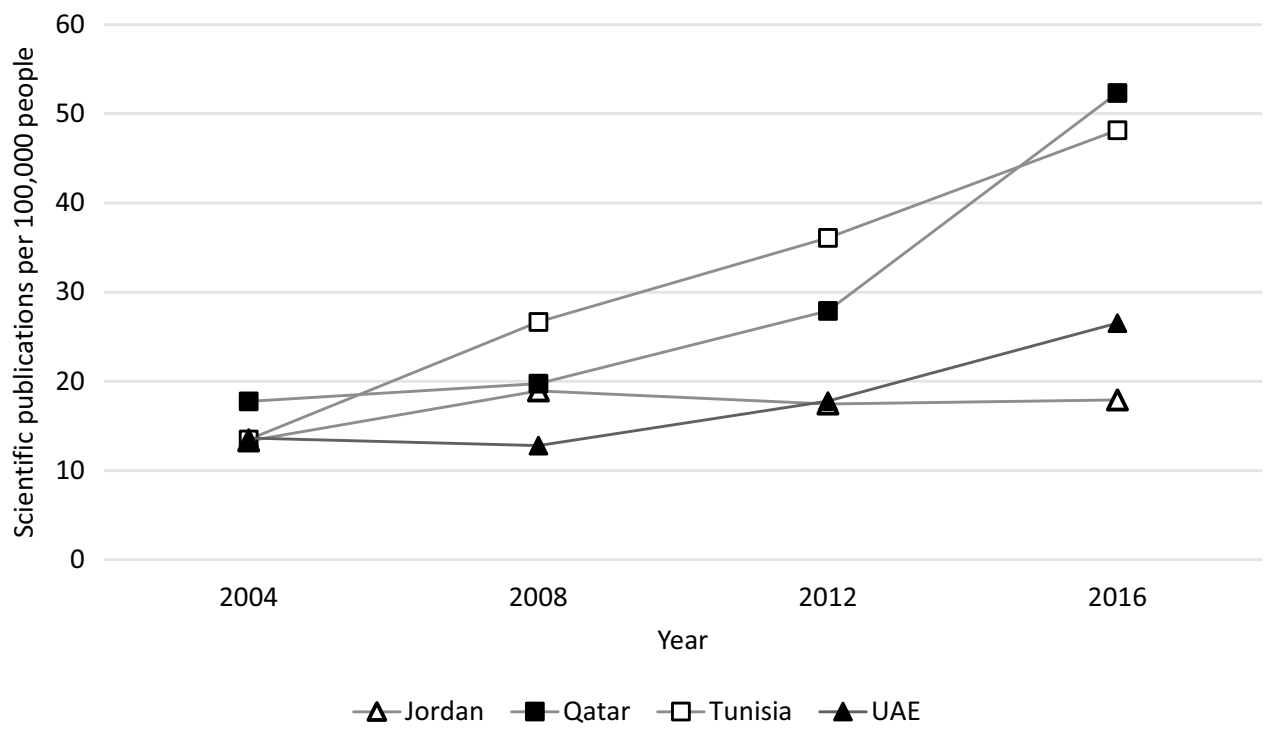

Source: Data accessed through the WB Open Data module for Stata. Indicators IP.JRN. ARTC.SC (Publications); SP.POP.TOTL (Population)

Qatar's approach to supporting research has been more recent and has come from the top. Qatar has fully embraced a knowledge economy discourse that pervades its education, science, and development policies. Since its establishment in 1995 the Qatar Foundation has aggressively pursued its goal of turning Qatar into a knowledge economy. Over the past two decades its initiatives have included creating Education City, with its eleven branch campuses and one Qatari graduate institution; founding three new research institutes; sponsoring dozens of global competitions, summits, and conferences; and spinning off new civil society organizations. In 2019 it advertised itself as having fifty affiliated initiatives. Romani (2009) states that the goal of these initiatives is "to change Arab academe from a site for knowledge reception to one of knowledge production" (p. 4). The Qatar Foundation has begun emphasizing the word homegrown in its recent publications, indicating a desire to shift from being a funder and importer of knowledge to being a local producer and exporter of its knowledge. In the next section I discuss the varied ways in which Qatar is supporting a culture of research. 


\section{"Publications Have Soared" in Qatar}

Despite the clear growth in scientific publication rates shown in figure 6.3, there is much that publication rates do not tell us, such as how Qatar and Tunisia increased their publishing productivity, what types of publications are captured by these statistics, who is conducting research, and on what topics are they focusing. In March 2019 I travelled to Doha to understand how the country had supported research and knowledge production in line with broader development mandates. There was widespread acknowledgment that the country's leadership had explicitly invested in creating an ecosystem and infrastructure to support research. One scholar with whom I spoke put it simply: "There was the feeling that there wasn't enough research." The effort to support research has been led primarily by the Qatar Foundation in line with its broader mission. In 2006 it established the Qatar National Research Fund (QNRF) to provide funding for Qatari researchers "as part of its ongoing commitment to establish Qatar as a knowledge-based economy." The importance of research is clearly articulated on QNRF's website, which states that the Qatar Foundation "views research as essential to national and regional growth, as the means to diversify the nation's economy, enhance educational offerings and develop areas that affect the community, such as health and environment."

Expanding graduate education has also played a role. In 2010 the Hamad Bin Khalifa University was established as a graduate-level Qatari university. Although it is situated in Education City, the same campus complex as the Qatar Foundation's branch campuses, it is considered a homegrown institution. As of 2017-18, the university had over six hundred students, of whom 43 per cent were Qatari (PSA, 2018). Three research centres are affiliated with Hamad Bin Khalifa University, each with a focus on a particular scientific area: the Qatar Biomedical Research Institute, the Qatar Computing Research Institute, and the Qatar Environment and Energy Research Institute. A fourth, focusing on the social sciences, was planned but never opened. These well-funded institutes have developed infrastructure and equipment to support high-calibre research, recruited international researchers, and funded generous two-year post-doctoral fellowships.

In addition, the country's national public university, Qatar University, now offers doctoral programs and has launched post-doctoral fellowship programs that recruit early-career researchers to produce research in Qatar. Initiatives reflect a commitment to building a culture of research through programs such as an annual undergraduate research competition and leadership programs for female researchers. The undergraduate 
research competition, which began in 2007, provides both funding for undergraduates to undertake research and cash prizes for competition winners. The programs stated goals are to build a culture of research and bring attention and prominence to research as a career option. Many scholars with whom I spoke agreed that these programs have had an impact. One researcher explained: "Ten years ago, you would never hear about research. Now we get surveys on some research topic or another all the time, almost every day. And publications have soared."

Others, however, both inside and outside of Qatar, are sceptical. Some argue that indicators of productivity are easy to manipulate, particularly in a small country such as Qatar, where a few publications can influence per capita numbers. Indeed, UNESCO (2016) reports that international co-authorship in Qatar has soared, from 52 per cent of publications having an international collaborator in 2005 to 92 per cent in 2014, suggesting that international collaboration is indeed a major factor in Qatar's growth. Opinions of these collaborations are nuanced. One researcher in Doha explained: "So there is the criticism that expats are the ones primarily doing the research. It's true, but the critical mass of Qataris is small. There aren't thousands, or even hundreds of researchers, but there are dozens of Qataris who are now active in research." He noted that a culture of research was becoming institutionalized: "the leadership has created the ecosystem for research."

Although the Qatar National Research Fund is narrowly tailored to the needs of Qatar, the benefits of investments in research are rarely limited to one country. In my visit to Qatar I was reminded of the importance of what cross-cultural insights can bring to our collective knowledge. Georgetown University's School of Foreign Service-Qatar has a series of research papers on how an Islamic world-view actually enables, rather than constrains, scientific research. One project found that research on stem cells was actually supported much earlier in certain Islamic countries than in the West: in the United States, stem-cell research generated significant political backlash in the early 2000s from Christians who believed that life began at conception. In an Islamic world-view, however, human life (or ensoulment) is typically thought to occur 120 days after conception. In 2002 the supreme leader of Iran issued a fatwa stating that stem-cell research was a moral good that could help ease human suffering. Qatar has since followed suit with a strong program of stem-cell research (Saniei \& Baharvand, 2018). Recognizing research as the social construction of knowledge shines a light on how researchers in Western countries, who have inherited ideals of the Enlightenment and operate within legal systems informed by Christianity, are also historically particular. 


\section{The Doha Institute's "Different Approach"}

In 2011 Qatari leadership founded the Doha Institute for Graduate Studies as what one of my interviewees called "a different approach" to local knowledge production. The founding vision for the Doha Institute came from Azmi Bishara, a Palestinian Arab intellectual and former member of the Israeli legislature who now lives in Doha in voluntary exile. Funding for the institution is provided by the Qatari royal family. The Doha Institute is unique in Doha and the Arab world: it is an independent graduate-level institute that focuses on the social sciences and humanities. Its programs include public administration, economics, and conflict and humanitarian studies. What sets it apart from institutions in Education City is that, rather than importing English-language programs from North America and Europe, the Doha Institute uses the Arabic language as the primary medium of instruction, publication, and public discourse. English is called a "companion language" for learning and scholarship, and graduates are expected to be bilingual. The promotion of Arabic-language research production is one way in which Qatar is embracing the role of promoting Arabic throughout the Middle East region. Such a role clearly maps onto Qatar's broader geopolitical ambitions of elevating its status in the region, including high-profile projects such as Al Jazeera and Qatar's decision to bid on and host the 2020 FIFA World Cup.

In March 2019 I visited the Doha Institute to understand how it was accomplishing its unique mission. What I found was a small but beautiful campus with gleaming white buildings decorated with geometric patterns that invoke traditional Islamic architecture, and inviting rows of palm trees and fountains. Posters in both Arabic and English advertised talks by professors around the region. An administrator explained that its focus on social sciences also makes it distinctive. One administrator explained: "In the region, there has been a technical and vocational focus. Many people think, Who would study history?"

As with any new educational initiative, however, the reality is complicated and the challenges are clear. Both faculty members and administrators said that a lack of permanence was a key challenge. Almost all the faculty members at the Doha Institute are non-nationals. This is the reality in most higher education institutions in Qatar, as Qataris make up only 10 per cent of the country's population, and only a small number of Qataris have doctorates. Those that do tend to have them in applied and technical fields such as engineering. As a result, the number of Qataris who can be employed by a graduate-level institute in the social sciences is very small. Most faculty members at the Doha Institute have 
been recruited from well-known universities in the Arab world, including those in Jordan, Lebanon, Tunisia, and Egypt, or as young scholars who have returned from studying in the United States or Europe.

As non-nationals, they must rely on the visa sponsorship system (kafala, Arabic), which means that their livelihoods and lives in Qatar are tied to their employment. This system creates a deep-seated sense of instability for faculty members. One non-Qatari explained: "In the GCC, we don't have stability. There's no guarantee of tenure. It hurts our production of knowledge. How can you study what you want to study when your job stability and security is linked to it?" Another stated: "They bring me here, they give me money, but not stability." On the one hand, a lack of security likely contributes to self-censoring. On the other hand, it also affects research productivity in less direct ways. One administrator at the Doha Institute said that without a sense of permanence many faculty members felt as though they were merely passing through, which undermined their motivation for conducting research in Qatar. One professor explained: "The issue starts with security - people don't feel like they really belong here or that they have a future even after ten years. There is no security." Issues of legal status are not fully within the university's control. One professor at the institute said that "even if the university provides stability, your visa might not be renewed by the government, and this is outside the control of the university."

The sense of precariousness was also linked to how the university was governed and seemed to undermine the institution's ability to accomplish its goals. One administrator explained: "The administrators and leaders want to keep their posts, and this affects how the university is run. There is a focus on just making people happy, not doing what you have to do to improve quality."

Beyond day-to-day administration, the structures of the global academic system also impose constraints. Professors and administrators remarked that despite a sincere commitment to using Arabic as a language of teaching and research, it was "hard to focus on Arabic," because "there's no system for publishing in Arabic, no impact factor, no rankings." Indeed, many of the younger faculty members at the Doha Institute have been recruited as recent doctoral graduates from North American and European institutions; they have been trained in English and prioritize publishing in peer-reviewed and internationally recognized journals. One professor explained that for assistant professors who were trying to establish their reputation as scholars in their disciplinary fields, it was crucial that they publish in ranked disciplinary journals, which were almost all in English. Many of these younger 
faculty members stated that they had little incentive to stay at the Doha Institute or to publish in Arabic if they could move to a university in North America or Europe that could provide a sense of permanence.

Even in the short time I spent at the Doha Institute, I had a sense of the challenges it faces: the Doha Institute represents an alternative model for higher education in a world where success is measured by a single yardstick. One administrator told me: "I'm not certain we will succeed in our mission. I'm not very optimistic. But we have to be patient. We have to say we are here to do something different."

\section{The Hollow Discourse of Productivity}

Despite the success of some of these initiatives, the narrow focus on research productivity rings hollow when divorced from broader discussions of who is producing knowledge, and how and why they are doing so. Research is fundamentally a social enterprise, and the political climate and geopolitical context, including neoliberalism and securitization, have undermined the independence of Arab academics. In this section I discuss how neoliberal ideologies and crackdowns on academic freedom have affected research production in the region.

Knowledge economy discourses and neoliberal ideologies have incentivized "outputs" in the form of publications and patents. Increasingly, professors are encouraged to publish in peer-reviewed, internationally ranked journals, with promotions or pay often linked to publishing (Austin et al., 2014; Hanafi, 2011). The global publishing industry is dominated by journals based in Europe and North America that publish in English and give priority to universalizing claims, rather than to localized or contextualized knowledges. Professors in the Arab world must often publish their research in English and frame their questions around topics that are of interest to global or transnational audiences, rather than local or national audiences (Hanafi, 2011; Hanafi \& Arvanitis, 2014). In interviews in Qatar, where institutions have fully embraced an output-oriented strategy including annual productivity reviews, and promotions and job stability tied to outputs, professors explained the perverse incentives induced by this approach. One professor stated: "They care about numbers of articles. They don't realize it can take years to do work that is truly impactful."

Sari Hanafi, a professor of sociology at the American University of Beirut, describes the dual experience that Arab academics face. When he publishes in English in peer-reviewed sociological journals, he often garners attention and acclaim from scholars based in North America or Europe who find his work useful to their own theories (Hanafi, 2011). 
Meanwhile, few Arab students or scholars have access to those same articles. In contrast, when he publishes in Arabic or writes as a public intellectual in the Arab media, he is often contacted by students and scholars throughout the Arab world and thanked for his contributions. He argues that one of the ramifications of this linguistic divide is that social scientists in the Arab world are financially and professionally incentivized to do research that appeals to readers in North America rather than Arab publics. It often incentivizes a priority on theoretical research, rather than locally relevant or applied knowledge that may inform important policy domains of Arab societies.

This linguistic divide not only has ramifications for what Arab academics publish, where, and in what languages, but also affects the topics they research (Hanafi \& Arvanitis, 2014). In a rare study of how the language of publication affects the topic of research, Waast et al. (2010) explore the full holdings of the King Abdul-Aziz Foundation library in Casablanca, Morocco, which, since its founding in 1980, has been committed to gathering all social science publications, in any language, that focus on North Africa. Their bibliometric analysis shows clearly that research topic maps onto language of publication. In examining publications by authors originally from North Africa, they find that the vast majority of publications on philosophy, Islam, history, and education are published in Arabic. In contrast, only 20 per cent of publications on economics and 10 per cent of publications on management are published in Arabic. They argue convincingly that topics deemed important to the "current global research agenda," namely women, the environment, public policy, urban studies, and globalization, are more likely to be published in languages other than Arabic, and presumably French and English, while those related to "cultural life, education and local history" are more likely to be published in Arabic (p. 178).

The determination of what counts as 'interesting' may also be in the eye of the funder. Shana Cohen, drawing on decades of ethnographic work in Morocco, finds that Moroccan academics increasingly spend their time working on policy-relevant research funded by international development agencies. She argues that in the nation-building era, public funding for higher education creates the material conditions necessary for a critical and publicly engaged academia by providing "the material resources and cultural and ideological impetus for critical academic research and analysis" (2014, p. 31). In response to neoliberal austerity, however, many Moroccan academics find that consulting work is the only source of funding for research and turn to it due to a lack of other funding. Cohen acknowledges the benefits of consulting for academics: "The attraction of the remuneration offered by consultant work is 
legitimate: it offers the possibility of conducting applied research and benefitting from some kind of recognition. It offers as well the revenue for paying off debts and the children's school fees, as enough faculty want to avoid public education. Who can blame them?" (2014, p. 35).

This culture of consulting, however, narrows topics and turns research into concrete deliverable products. Consulting qua research elevates the profile of certain well-known intellectuals, who lend their expertise and credentials to a narrow set of topics outlined by state actors or development agencies, such as the middle class, employment, youth, and education. In so doing, it tends to ignore more theoretical topics, as well as the humanities and critical scholarship. Moreover, academics' participation in the consulting industry creates a set of shared interests between state actors, funding agencies, and intellectuals. After interviewing prominent academics and intellectuals, the French magazine Tel Quel reported on the "silence of the intellectuals" in Morocco. The 2009 article argues that inevitably "intellocrats" - a term they use to describe intellectuals who focus their expertise on the administration of policy - "end up legitimising, if not all aspects of government strategy, at least the power of politicians and their stewardship of the country" (cited in Cohen, 2014, p. 36). Cohen asks if the continual assault on the university as a public institution and the increasing ideological linkages between the university and knowledge economy discourses and neoliberal policies has fostered a sense of "opportunism" among Arab academics, "rather than a desire to contribute to non-materialistic collective goals" $(2014$, p. 40). She worries that the pervasiveness of neoliberal ideologies has cemented a new culture of the high-profile academic, arguing that "the same cohort of academics that engaged with nationalist and Marxist ideas have taken on consulting contracts, in part for the funds, but also for the prestige and status of working within international networks and close to government officials" (p. 41). There is a noteworthy arrogance in the assumption that the West can afford to fund basic research, while research in the Arab world must be applied, relevant, and marketable.

In addition, knowledge production and investment in scientific research in the region are undermined by excessive spending on militarization and geopolitical conflicts (UNESCO, 2015). Research priorities are frequently determined by what the governments perceive to be pressing national security or geopolitical concerns, which in the Arab world include energy, water, and food security (Badran, 2018). However, an over-emphasis on national security and a lack of actual security undermine academic communities. In their analysis of research productivity over twenty years, Waast and Rossi (2010) argue that 
scientific production "mirrors political turmoil, vagaries of state support and the turnabout of development policies" (p. 344). They point to earlier conflicts, including the Lebanese (1975-90) and Algerian (1991-8) civil wars and the first Gulf War (1990-1), as periods when research productivity stalled in these countries. More recently, the political and economic crises affecting the region in the twenty-first century, including the invasion of Iraq, the Arab Spring, the Syrian civil war, and the rise of the Islamic State of Iraq and Syria (ISIS), have been disastrous to respective academic communities (Almansour \& Kempner, 2017; Dillabough et al., 2018) and resulted in significant brain drain.

\section{Academic Freedom}

Another political constraint to research productivity in the Arab world is a general lack of academic freedom (UNDP, 2003; Waterbury, 2020). Although the low levels of academic freedom in the region are widely acknowledged, the technical literature that decries low research productivity in the region sidesteps discussions of academic freedom by emphasizing the need for applied and supposedly apolitical science. In this section I argue that the lack of academic freedom in the region is not a coincidence; it is inherent in an institution that is tied closely to broader webs of power in the region, including state and religious authority.

Academic freedom is the ability to pursue independent research and discuss ideas in the classroom with little to no external interference. In the European tradition of higher education, over many centuries universities have secured a buffer from state authority. Professors are typically respected as professionals and given autonomy in their teaching and research. They are primarily accountable to the other professors in their fields, who judge the merits of their work. Even in public universities, when professors are government employees, they are protected from direct state control by the independence of their institutions, faculty associations, and obligations to non-state actors, including students, private businesses, and alumni. Of course, in practice, academic freedom is more of a norm than a right, and has always been susceptible to violation, even in liberal democracies (Altbach, 2007; Waterbury, 2020). Yet, for over a thousand years universities have negotiated the fine line between supporting the governments that authorize and regulate them and critiquing those same governments. This freedom allows professors to pursue their research and participate in public commentary without fear of being punished or silenced. More broadly, academic freedom is viewed as a cornerstone of the scientific process that permits critical debate and exchange of ideas. 
It is this Western view of academic freedom that has been enshrined in powerful global organizations. The 1997 UNESCO "Recommendation Concerning the Status of Higher-Education Teaching Personnel" includes a definition of academic freedom that ensures a degree of autonomy for faculty members:

Higher-education teaching personnel are entitled to the maintaining of academic freedom, that is to say, the right, without constriction by prescribed doctrine, to freedom of teaching and discussion, freedom in carrying out research and disseminating and publishing the results thereof, freedom to express freely their opinion about the institution or system in which they work, freedom from institutional censorship and freedom to participate in professional or representative academic bodies. All higher-education teaching personnel should have the right to fulfill their functions without discrimination of any kind and without fear of repression by the state or any other source. (UNESCO, 1997, para. 26)

Arab scholars have long recognized that this definition of academic freedom hardly applies to the conditions of their work. An academic in the Arab world, Hanada Taha-Thomure (2003) describes growing up in Beirut and teaching primary school in Oman and Bahrain, and she states: "I did not fully experience an educational atmosphere in which professors engaged us on issues, especially if the discussion led to dissent with traditional interpretations of Islam or to criticisms of ruling regimes. Such topics were and still are not open for discussion" (p. 7). Waterbury (2020) reminds us that even while university autonomy and academic freedom are included in Arab universities' founding statements, these guarantees mean little. He quips: "Just as lip service is paid to university autonomy in official documents in the Arab world, academic freedom is similarly enshrined. Nowhere is it respected" (p. 129).

Throughout the region freedoms of all sorts are curtailed in the name of stability and security, and academic freedom is no exception (Grimm, 2018). Sociologists of the state remind us that the schools and university, along with other institutions such as the church, media, and cultural institutions, serve the interests of the broader political system. In place of professional autonomy and peer regulation is external oversight, with both teaching and research being controlled by political authorities (Osman, 2010; Waterbury, 2020). The irony is that in the Arab world, as in many post-colonial settings, the same national universities celebrated as sites of anti-colonial protest that helped to establish their modern nation states are now closely regulated and monitored as sites of potential anti-regime activism. 
In Egypt a law dating back to 1936 (Law 20) allows the Ministry of Information to screen all imported books and periodicals. Article 9 states that "in order to maintain public order, it is permissible to prohibit printed matter that is produced abroad from entering Egypt, and this prohibition can come as a special decision from the Committee of Ministers." Similarly, article 10 states: "The Committee of Ministers also has the right to ban the distribution and handling of printed matter of a sexual content as well as that which addresses religions in a way that could destabilize public peace." Combined, these two articles give the government the power to censor curricular content in politics, religion, and sex.

There is also a long history of security presence on campuses in the region, including in Egypt, Jordan, Tunisia, and Syria. Campus police and intelligence personnel, known as the mukhabarat, have been pervasive on university campuses, some visibly, others less visibly (George, 2003; Waterbury, 2020). In Egypt during the Mubarak era, plain-clothed police were stationed on university campuses and would call students' personal cell phones to inform them that their actions were being monitored. In Tunisia before the revolution, foreigners needed permission from the Ministry of the Interior to enter campus. Although that law has now been abolished, security guards still make their presence known on campuses. In 2013 I was stopped by security guards at El Manar University outside Tunis for taking a photograph of the campus.

National governments also exert power over universities by controlling appointments (Waterbury, 2020). Despite some initial commitments to autonomy, most public universities in the region lost their independence during the nation-building era. In many countries, including Egypt and Syria, presidents of universities are appointed by political leaders, rather than elected by faculty members, and the tradition of political control remains strong. In Jordan the king must approve appointments of university presidents, and all professors must pass a security check by the state's security police. Jordanian professors told me that they understood these security checks as a form of ideological policing, rather than simply a check of one's criminal record. Brand (1988) has argued that faculty member dismissals were used as "a political weapon" to maintain control of the faculties (p. 208).

Following Egypt's 2011 revolution there was optimism that conditions would improve, and legislation was passed to allow faculty members to elect university leaders directly - an indication of greater autonomy (L. Anderson, 2012). Those advances were quickly reversed, however. Since the military coup in 2013, in which Abdel Fattah al-Sisi ousted Mohamed Morsi, Egypt has experienced rising authoritarianism, and crackdowns on academic freedom have become even more 
prevalent (Holmes \& Aziz, 2019). Professors must obtain approval from security forces to travel abroad for academic reasons such as attending a conference or serving on dissertation committees, and a number of prominent Egyptian academics have been banned from travelling abroad. The Egyptian president regained the power to appoint university presidents and deans. Security forces are allowed on campuses, and university facilities can be designated military installations.

In 2013, Emad El-Din Shahin, a professor of political science at the American University in Cairo, was indicted for conspiring with outside organizations to undermine Egypt's security. In an interview with the newspaper Al-Fanar, he explained the surreal absurdity of his situation: "I was abroad giving lectures about - (laughs) - the peaceful resolution of conflict. Someone on Facebook informed me that I was a defendant in a high-profile case. The charges were very vague, like 'grand espionage' that's what they call it, smuggling arms, forcing the armed forces to move from the eastern front to the western front, etc. There was no evidence against me whatsoever. My lawyer said that if he built a defence strategy, he would be in jail next to me. So I left Egypt" (Bollag, 2016).

In May 2014 Sisi issued a ban on all academics leaving the country without prior governmental approval, which limits the number and types of conferences in which they can participate. Such a blanket ban is in direct violation of article 21 of the Egyptian constitution, which guarantees the independence of academic institutions, and of article 62 , which prevents the government from banning freedom of movement. In 2015 one researcher declared the state of academic freedom in Egypt under the Sisi regime as the "lowest point of academic freedom that the country has known" (Linn, 2015). In June 2016 Mozn Hassan, the founder and director of Nazra for Feminist Studies and a women's rights activist, was prevented from leaving Egypt because of her political activism. A similar scene played out when a prominent democracy advocate and professor of political science at Cairo University, Ahmad Hamzawy, was prevented from taking a leave of absence in 2014 and then terminated in 2017.

Research permits can also be denied for arbitrary and vague concerns about security. In recent years professors have been directly targeted by state authorities. In 2016 the German University of Cairo professor Tarek Abol Naga had his contract terminated because the research he was supervising on architecture was deemed "immoral" (el-Galil, 2016). Research support from foreign foundations or agencies raises red flags because the government is suspicious of foreign governments promoting democracy and civil society. Nader (2016) reports in $\mathrm{Al}$-Monitor that receiving funds from foreign donors, universities, or 
institutions is considered espionage in Egypt. In 2016 I was invited to speak at a number of universities in Egypt to discuss higher education admissions. As a foreigner, $\mathrm{I}$ had to receive specialized permission from the Department of the Interior to enter the campuses, which took weeks to obtain. The atmosphere was markedly different from my prior visits in 2007 and 2010. In the wake of student protests, all security on university campuses was outsourced to a private company, Falcon Group International, which has close ties to the Sisi regime. Although I received my permit, in many cases foreigners are denied access to campuses, which has had a dramatic impact on international collaborations and cross-border initiatives. An Egyptian colleague explained: “They think every foreigner is a spy. It's all politics. How do you think deans and university presidents make it to where they are? It's all through security. They can't get to where they are without reporting on their colleagues to security."

These crackdowns on academic freedom have been part of a broader trend towards rising authoritarianism in the region, typically justified in terms of national security. Table 6.3 reports on crackdowns on academic personnel between 2010 and 2019 from data collected by the Scholars at Risk (SAR) Academic Monitoring Project. SAR, a civil society organization based in New York, culled media reports to compile data on six different types of threats to academic freedom, from violence to firings to travel restrictions. The table shows a significant number of concerning incidents, particularly in Egypt, where forty-five documented incidents have occurred since 2010, and nine in the UAE, a much smaller country. In 2019 SAR and the Association for Freedom of Thought and Expression in Egypt asked the United Nations' Universal Periodic Review to examine attacks on higher education in Egypt as a human rights issue.

In Morocco, a prominent political activist and professor at Mohammed V University in Rabat, Maati Monjib, went on a hunger strike in 2015 after he was banned from leaving the country to attend a conference in Spain on political transitions. The repression of Monjib is part of a broader trend of crackdowns on political dissent in Morocco in the wake of the country's Arab Spring protests, known as the February 20 Movement. The government accused Monjib of "threatening national security" by organizing a training for journalists (Strangler, 2018).

In the Arab Gulf states, observers have also expressed rising concerns over threats to academic freedom. In 2011, Mohammed al-Ajami, a Qatari citizen, who was a third-year student in literature at Cairo University, was reciting poetry that supported the protests in Tunisia and was surreptitiously videotaped on a mobile phone. In November 
Table 6.3. Crackdowns on Academic Personnel, 2010-19

\begin{tabular}{llllllll}
\hline & $\begin{array}{l}\text { Killing \& } \\
\text { violence }\end{array}$ & Prison & Prosecution & $\begin{array}{l}\text { Loss of } \\
\text { position }\end{array}$ & $\begin{array}{l}\text { Travel } \\
\text { restrictions }\end{array}$ & Other & Total \\
\hline Egypt & 9 & 12 & 7 & 7 & 6 & 0 & 45 \\
Jordan & 1 & 1 & 1 & 0 & 0 & 0 & 3 \\
Lebanon & 0 & 1 & 1 & 0 & 0 & 0 & 2 \\
Morocco & 0 & 2 & 0 & 1 & 1 & 1 & 5 \\
Tunisia & 0 & 0 & 1 & 0 & 0 & 1 & 2 \\
UAE & 0 & 3 & 2 & 0 & 4 & 0 & 9 \\
\hline
\end{tabular}

Source: Scholars at Risk Academic Monitoring Project (2019)

2011 he was summoned to Doha, questioned by Qatar's security forces, and subsequently charged with "encouraging an attempt to overthrow the existing regime" and "criticizing the Emir." Initially he was sentenced to life in prison, subsequently commuted to fifteen years (MESA, 2016). In 2016 he was released after a royal pardon.

In 2011 five prominent activists known as the UAE5 were "arrested for crimes including insulting members of the country's ruling families and for posing a threat to state security," according to the National, a government-aligned newspaper in the UAE ("Five Emiratis," 2011). One of the arrested academics was Nasser Bin Ghaith, an Emirati human rights activist and economics professor at Sorbonne University Abu Dhabi. The imprisonment of Bin Ghaith has been criticized as undermining the values of freedom of speech in the region. A spokesperson for Scholars at Risk stated that the detention of Bin Ghaith was "a serious and unfortunate blow to the many good efforts of the government and others to develop the Emirates' reputation and position as a centre of knowledge, education and culture, as these can only flourish in places which respect intellectual enquiry, free expression and human rights" (O'Malley, 2011). SAR's advocacy campaign eventually led to the pardoning of Bin Ghaith.

Since the Arab Spring, crackdowns on social scientists in the UAE have deteriorated further. In 2013 the London School of Economics (LSE) called off a conference that had been scheduled at the American University of Sharjah in the UAE on the causes and effects of the Arab Spring, due to "threatened academic freedom" after a senior academic from the school was detained by immigration authorities at the Dubai airport and denied entry to the UAE. In a statement to the $B B C$ a university representative said that "the decision was made in response to restrictions imposed on the intellectual content of the 
event that threatened academic freedom" (Law, 2013). One of the ironies is that LSE receives significant funding from the UAE; at the time the conference was cancelled in 2013, the LSE had received USD 8.5 million from the Emirates Foundation, which is funded by the UAE government.

Debates over academic freedom at American branch campuses in the Arabian Gulf have also played out in the international media (Koch \& Vora, 2019). The UAE has banned several professors from entering the country, and details of these incidents routinely appear in the press. In 2015 Andrew Ross, a professor at New York University who studies migration, was prohibited from boarding a plane to the UAE "for security reasons." Ross explained: "We've been told by our administration that they have agreements with our Abu Dhabi partners about protecting academic freedoms and now it turns out that they really don't have that kind of influence ... They don't really have any say, ultimately, if the state decides to override those protections" (Redden, 2015). In 2018 NYU's College of Journalism suspended its collaboration after two of its journalism professors were denied visas into the UAE. In an opinion piece published in the New York Times, one of those professors, Mohamad Bazzi, claimed: "the promise of academic freedom has proved to be largely worthless" (Bazzi, 2017). The Middle East Studies Association's Committee on Academic Freedom made it clear that the UAE's security agenda was at odds with its stated attempt to be a regional knowledge hub, and warned that "it has become obvious that there has been an escalation in insecurity for researchers" (MESA, 2018).

Crackdowns on the pursuit of knowledge are part of the control by a government over the ideological institutions of its country. They also raise a fundamental question concerning the link between higher education and a knowledge economy: can one build a knowledge economy and research culture without respect for fundamental academic freedoms, including the right to critique those in power? The result of these many years of attacks on academic freedom is self-censorship and a focus on technical knowledge rather than on social, cultural, or political knowledge.

In 2016, I spoke with a professor at a public university in the UAE who framed the debate as central to the question of democratization: "What is the right amount of education needed so that Emiratis can replace Westerners at certain jobs at the oil companies, but then, don't really create an independent, free-thinking, critical-thinking society? We have seen in the West that when you create an educated class, they have always turned on the totalitarian government, call it monarchy or whatever you like. Can we find a balance in the Arab world, where we have an inherited ruler, not a democratic government, and create 
a knowledge society? Because I think that is the ultimate debate: are those things mutually exclusive?" This professor's question applies no less to the Arab world than to many parts of the world where we have witnessed crackdowns on academic freedom, including China, Hungary, and Turkey.

\section{Between Knowledge and Truth}

The university has long been a creator and disseminator of knowledge. Around the world, countries are reforming their universities to be engines of economic growth by emphasizing quantitative research outputs in targeted sectors. These reforms have been adopted throughout the Arab world, where knowledge production is emphasized in official documents and policies and linked to countries' participation in the global knowledge economy. On the one hand, there is much to celebrate in the region: in middle-income countries in particular, research productivity rates are above average for countries of similar levels of economic development. These updated and contextualized data should put to rest the idea that the Arab world is truly failing in knowledge production.

On the other hand, the focus on research productivity may actually be harmful. The framing of productivity as an individual or institutional output ignores the structural conditions that shape research production including national wealth, academic freedom, academics' professional identities, universities' organizational cultures, and the hegemony of English globally. The link between research and university rankings also pushes Arab academics to prioritize the global and the abstract, at the expense of the local and the particular. Meanwhile, the focus on applied and useful research in the name of economic development emphasizes the natural sciences and technological development at the expense of the social sciences and the humanities. Some of the most pressing, yet politically contentious, questions the region faces involve the "messy" social sciences and the "fluffy" humanities that are too often dismissed, including questions of identity, inequality, cultural difference, civic engagement, and subjective well-being. 